International Journal of Social Sciences and Humanities
Available online at http://sciencescholar.us/journal/index.php/ijssh
Vol. 2 No. 3, December 2018, pages: 156 172
e-ISSN: 2550-7001, p-ISSN: 2550-701X
https://doi.org/10.29332/ijssh.v2n3.226

\title{
Improving Policy of the Republic of Indonesia Performance in Bali Regional Police Environment
}

\author{
I Ketut Astina a , Agus Sukristyanto ${ }^{\mathrm{b}}$, Arif Darmawan ${ }^{\mathrm{c}}$
}

Article history: Received 8 April 2018, Accepted: 30 August 2018, Published: 26 November 2018

\section{Correspondence Author a}

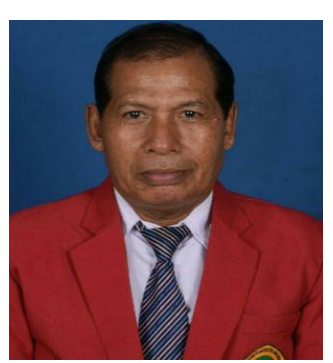

Keywords

additional income; performance benefit; policy performance; policy; remuneration;

\begin{abstract}
This current study is aimed at analyzing the policy which is made to improve the performance of the Police of the Republic of Indonesia in general and the Bali Regional Police in particular when serving the public, the model of formal policy which is expected to increase the income earned by those who are employed at the Operating Bureau of the Bali Regional Police, and the factors hampering the attempts made to improve the performance of the police of the Republic of Indonesia when serving the public in the Bali Regional Police. The study focuses on the policy issued to give remuneration and the performance of being prepared to serve the public. The study is also intended to evaluate to what extent the policy of giving remuneration can lead to the achievement of the goal and target already determined. One of the goals which are intended to be achieved is to improve the performance of the Police of the Republic of Indonesia when serving the public. The result of the study showed that the remuneration as the policy made for those who are employed at the Bali Regional Police in general and those who are employed at the Operating Bureau of the Bali Regional Police, in particular, did not significantly contribute to the services they gave to the public. The result of the study also showed that the Model Policy applied to give remuneration to those employed at the Operating Bureau of the Bali Regional Office Police could not satisfy what had been expected by the Bali Regional Police. The cause was that the value of the remuneration was not justly determined.
\end{abstract}

e-ISSN: 2550-7001, p-ISSN: 2550-701X ${ }^{\odot}$ Copyright 2018. The Author. SS Journals Published by Universidad Técnica de Manabí. This is an open-access article under the CC BY-SA 4.0 license (https://creativecommons.org/licenses/by-sa/4.0/) All rights reserved.

\section{Contents}

Abstract 156

1. Introduction. 157

a Ngurah Rai University of Bali Indonesia, Denpasar, Bali, Indonesia

b 17 Agustus University of Surabaya, East Java, Indonesia

c 17 Agustus University of Surabaya, East Java, Indonesia 


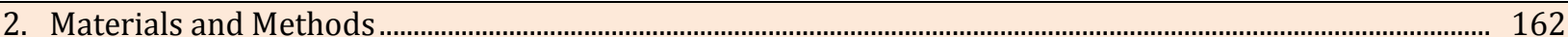

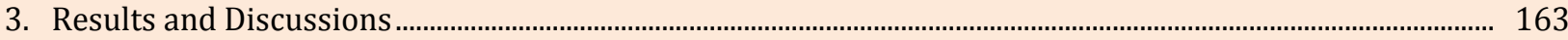

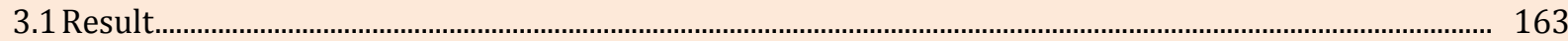

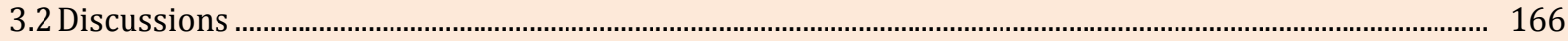

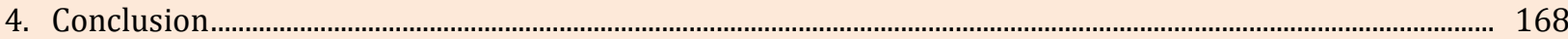

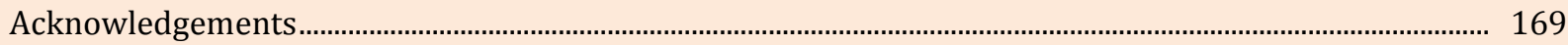

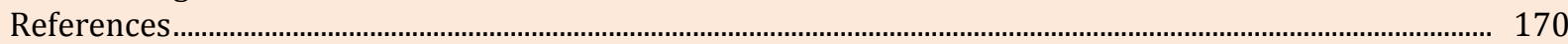

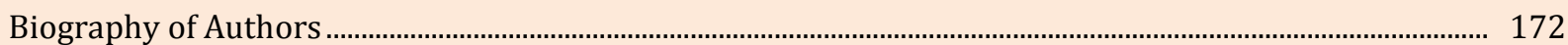

\section{Introduction}

The Act which is used as the basis for determining the responsibilities of the Police of the Republic of Indonesia is the Act No. 2 of 2002 concerning the Police of the Republic of Indonesia. Before this Act was in effect, the Act No. 28 of 1997 concerning the Police of the Republic of Indonesia (the Official Gazette No. 28 of 1997, the Supplement Official Gazette No. 3710) which was issued to complete the Act No. 13 of 1961 concerning the basic provisions of the State Police (the Official Gazette No. 245 of 1961, the Supplement Gazette No. 2289) were used as the basis.

The Act No. 2 of 2002 concerning the Police of the Republic of Indonesia was issued based on a new paradigm; therefore, it is expected that the position of and the role played by and the implementation of the responsibilities of the Police of the Republic of Indonesia, as an integral part of the whole reformation of the order of the life of the nation and State are to create a civilized, prosperous and civil society based on the Five Principles "Pancasila" and the 1945 Constitution.

The importance of improving the quality of human resources cannot be separated from the problem faced by the developing countries, as stated by Soemitro (2002) that the condition of the quality of human resources is the basic weakness of the developing countries, including Indonesia. In Indonesia in general and in the bureaucratic environment, in particular, the work climate influenced by the Collusion, Corruption, and Nepotism behaviors are still found. The individual quality of human resources is not used as the measurement of whether someone suits or does not suit the position where he/she is employed. Where someone is placed or the placement of someone is more determined by how close he/she is to his/her supervisor; in other words, professionalism, knowledge, skill, working experience and so forth do not determine where he/she is placed. It is no exaggeration to say that the competitiveness of the Indonesian bureaucratic human resources is much lower than that of those of the other countries such as Singapore and Malaysia.

Therefore, what is important is how to improve the human resources in the bureaucratic environment so that they can perform what they are supposed to do professionally. According to Suyata (2000), being professional means being skilled in and faithful to the application of the values of the truth procedurally and substantially based on the regulations of the law.

Discussing performance cannot be separated from the factors contributing to someone's performance. As revealed by the study conducted by the Center of Population of Gajah Mada Yogyakarta in 2002 that the indicators of the performance of bad public services are as follows: 1 . The public does not feel satisfied with the public services provided by the government bureaucrats in terms of the time taken, the cost they charge and the way in which they serve the public; 2. There is discrimination resulting from friendship, political affiliation, ethnicity and religious faith which usually cause the bureaucrats not to be neutral when serving the public; 3. The services provided to the public are not oriented towards the service user but towards the interests of the government and its officials; 4. The principle used as the basis for serving the public is the principle of distrust rather than the principle of trust; 5 . The procedure which is applied to serving the public is not the facilitating but the controlling behavior and authority to the public services become distributed in different work units of bureaucracy, causing the service users not to feel comfortable.

How the Bali Regional Police treats the Police often does not show the Police Performance. As an illustration, when budgeting is prepared, the Bali Regional Police does not relate the budgeting to the performance of the police at all. The budget allocated for the public services is based on input rather than output. The budget received by the Police is determined by the need rather than by the output yielded from

Astina, I. K., Sukristyanto, A., \& Darmawan, A. (2018). Improving policy of the Republic of Indonesia performance in Bali regional police environment. International Journal of Social Sciences and Humanities, 2(3), $156-172$. https://doi.org/10.29332/ijssh.v2n3.226 
the services provided to the public. As a consequence, the motivation to perform well in the life of the public bureaucracy tends to be low (Dwiyanto, 2012).

If society can be well served by the Police apparatus, then they will automatically be able to treat themselves as civil servants. Such a condition will contribute to the performance of the Police apparatus as what is expected by society. Finally, people will trust the Police apparatus. It is this which will make the Bali Regional Police advanced in serving its society, resulting in the transparent, accountable and clean Police apparatus.

The existence of the Police apparatus becomes important if the Police can support the public welfare through their function and role as the public servants. It is this which becomes the responsibility of the Police apparatus. Apart from that, the existence of the Police apparatus becomes the keyword to the continuity of the Bali Regional Police (Polda Bali) to serve the public. The big role played by the Police apparatus causes them to be needed by society and to have a strategic position in the life of the state and community. In addition, the Police apparatus also become the symbol of the sustainability of the system and identity of the Bali Regional Police; in other words, the Police apparatus also shows whether the Bali Regional Police works or does not work. The role and function of the Police apparatus determine whether the Bali Regional Police works or does not work.

This strategic dimension at least makes the existence of the Police apparatus becomes a topic of discussion which cannot be separated from its accompanying problems. There are many problems which need to be explored. They are: what the Police apparatus are like from their performance, ethics, and morality aspects; what the Police apparatus is like from the level of their welfare, and from the other dimensions which always cause the Police apparatus to be a discourse which is interesting to be discussed.

Apart from the aforementioned aspects, the condition of the Police apparatus still becomes a spotlight from the behavior, ethics and morality aspects. Many people consider that the Police apparatus do not work seriously. They only go to the office, and then they go home and wait for their salaries. This is not wrong as it seems that the Police apparatus have not been reorganized; their institution and basic responsibilities need to be reorganized. The Bali Regional Police is entering an era when the system of promoting the career of the members is badly managed. This condition is often not supported with any attempt to improve the standard of the competence of the Police apparatus, causing them not to have any clear working standard. Therefore, it is not surprising if there are some of the Police apparatus whose performance is low.

The good public services can be observed from the physical aspect of the services provided. As an illustration, the Building of the Operating Bureau of the Bali Regional Office headed by Head of the Operating Bureau of the Bali Regional Police serves to support the high-ranking staff directly under the Regional Police Chief (Kapolda) when supervising and managing the operating activities, including the pre-operating coordination exercise and cooperation as a part of the operation done by the police.

The personnel of the Operating Bureau of the Bali Regional Police can give comfortable services using supporting technologies such as a computer, CCTV, HT and so forth to support the operation needed to serve and secure the public. Therefore, it is highly important to improve the quality of Human Resources as an attempt to improve the services provided to the public. It needs to be perpetually improved to encounter what is demanded by the public.

The policy issued by the Bali Regional Office to give remuneration to its apparatus is expected to be able to improve the performance of the Police of the Republic of Indonesia. Therefore, the Bali Regional Police needs to maintain and improve such a policy.

The performance-based remuneration is a more modern and progressive concept which is expected to be able to improve the performance of the Police of the Republic of Indonesia significantly. The nature of the performance-based remuneration is not permanent and its value varies. The criteria used to determine the value of the remuneration are the knowledge and in-depth expertise and special skill the apparatus has, how risky their jobs are, and the other things technically related to the scope of their jobs.

The objective to issue the policy of giving remuneration is to improve the welfare of those employed at the Bali Regional Police and to inspire them to improve their performances. If this condition is not created, then they will feel unsatisfied. Therefore, the compensation system, according to Gibson et al., (2010), as the system, which regulates salaries, wages, allowances, incentives and the other forms of appreciation, is created to motivate or encourage the employees to show high performances. 
The things which need attention when planning the policy of remuneration are as follows: (a) the principle of being equitable and proportional; being equitable means that objectivity is needed to determine the nominal value, and being proportional means that the following things should be taken into consideration; (b) responsibility, namely what an employee is supposed to do, the value contributed by his/her position to the organization, which can be observed from 3 (three) things, namely the need for capability, the problem solving, and responsibility. The remuneration given to the employees employed by the Police of the Republic of Indonesia will be able to improve their performances when serving the public. It is expected that the development of the policy of remuneration for the employees employed by the Police of the Republic of Indonesia based on the workload, responsibility and performance can minimize the abuse of authority such as corruption, collusion and nepotism among them (Nahak, 2017).

The policy of remuneration created by the Bali Regional Police for its employees is expected to be able to improve their performances when serving and protecting the community. However, there are still some members who have not been able to improve their performances. The problem of the Operating Bureau of the Bali Regional Police is that the performances of its staff members have not been in accordance with what is expected, as can be observed from how they serve the public; 1 . some personnel lacks discipline and 2. Late decision making. The data on the sanctions imposed against the personnel of the Operating Bureau of the Bali Regional Police who lack discipline are presented. Based on the background described above, the problems of the current study are formulated as follows. 1 . What is the policy of remuneration which is made to improve the performance of the apparatus of the Police of the Republic of Indonesia employed at the Bali Regional Police when serving the public evaluated like, 2. How can the model policy of remuneration improve the performances of the apparatus of the Police of the Republic of Indonesia when serving the public at the Bali Regional Police?

\section{Review of Literature}

\section{a) Public Policy}

Public policy is basically defined as the realization of what is desired by social scientists to solve the social problems in the field (Parsons, 1997). Therefore, a public policy is considered the guidance chose by the decision maker to control particular aspects of a social problem. It has at least three dimensions which are related to one another; it has an objective, an authoritative choice, namely the choice of doing something legally, and a hypothesis (Bridgman \& Davis in Suharto, 2008). It is one of the interesting studies in political science. However, the concept the public policy is given more emphasis on the studies of the state administration, meaning that the public policy is only considered a process of making a decision used by the state by taking several aspects into consideration. In general, a public policy is defined as a policy or decision made by an authority (in this case the government) in which the stakeholders may be involved starting from when it is formulated to when it is evaluated. The social characteristic and social groupings have a great influence in determining the behavior of choosing the person (Agus Sukristyanto, 2018). Based on the theory proposed by Bromley in Tachjan (2006:17), a public policy has three different levels based on the hierarchy of the policy, namely: the policy level, the organizational level, and the operational level. In a democratic country, the role of the policy level is played by the judicative and legislative bodies, the role of the organizational level is played by the executive body, and the role of the operational level is played by the implementing units such as departments, institutions, or ministries. In each level, a public policy is in the form of an institutional arrangement or the regulations of law adjusted to the hierarchical level.

The policy of remuneration is a strategy made by the government to improve the welfare and performance of the government civil servants in Indonesia. It is expected that this policy can create a breakthrough to the phenomenon which shows that the current image of the state apparatus is not good. The fact that more and more corrupting behaviors exposed in almost every institution of the central and local governments worsen the image.

The policy of remuneration should be accurately planned and its objectives should be formulated in such a way that they can be used to guiding the program used to determine the optimal combination of allowances. Therefore, the following steps should be taken: 1 . The data on the basic costs of all the items of the allowance should be collected, 2. How much money is available should be explored; 3 . The costs included in the

Astina, I. K., Sukristyanto, A., \& Darmawan, A. (2018). Improving policy of the Republic of Indonesia performance in Bali regional police environment. International Journal of Social Sciences and Humanities, 2(3), 156-172. 
allowance should be referred to for the next period's payment; 4 . The preference to every item of the allowance should be determined using several types of balanced numeric scales in which the legal requirements of the preferences of the employees and management should be included; 5 . How different allowances are optimally combined should be decided. The careful decision maker will take different items and relative preferences shown by the management and employees, the estimation of the cost of every item and the grand total of the funds available for every package of allowances.

\section{b) Concept of Performance}

The job performance of human resources contributes to the success achieved by a public organization. Therefore, every public organization will do its best to improve the job performance of its employees in order to achieve the goal it has already determined. Basically, the job performance can be viewed from two aspects; they are the job performance of an employee and the job performance of the organization for which he/she is employed. The job performance of an employee refers to the output individually achieved in an organization and the performance of the organization for which an employee works refers to the total output achieved by the organization. Basically, the job performance is the output of the job done by someone based on the standard and criteria already determined. The job performance is one of the total collections of what is done by an employee. The job performance refers to the function of motivating and being able to complete any job or responsibility. In this case, an employee should be able to show how prepared he/she is and how successful he/she is. The job performance refers to how successfully someone can do his/her responsibility and how successfully he/she can achieve the goal already determined. If the goal desired can be well achieved, then his/her job performance can be stated to be good and successful.

Sedarmayanti (2009) stated that the job performance is a system used to evaluate and know whether an employee has been able to do his/her job completely, or that the job performance refers to the blend of what should be achieved by someone and how he/she achieves it (competence). The job performance is a condition which should be known and informed to particular parties so that they will know what should be achieved in an institution in its relation to its vision and the positive and negative impacts of the operating policy taken. The availability of the information on the job performance of a government institution leads to the measures which can be taken to revise the policy, revise its main activities and basic responsibilities, the material needed in the planning, determine the level of the success it should achieve to decide what to do and so forth.

\section{c) Evaluation of the Public Policy}

A public policy cannot be made without any further activities. It should be supervised, and one of the mechanisms through which it can be supervised is as follows: "evaluating the policy". An evaluation is needed in order to identify the gap between the fact and what is expected. It does not only lead to a conclusion which concludes to what extent a problem has been settled, but it should also clarify and criticize the values contributing to the policy, help adjust and reformulate the problem.

A policy should be evaluated as not all programs of the public policy are as successful as what has been desired. A public policy often fails to achieve the goal previously determined. Therefore, an evaluation is needed to identify what has led to the failure and whether the public policy already carried out has contributed to the impact desired. In short, evaluation is an activity which is intended to evaluate "the significance" of a policy.

In general, the evaluation of a policy can be stated to be an activity which is related to the estimation or evaluation of the policy which includes its substance, implementation, and impact. In this case, the evaluation of a policy is considered a functional activity, meaning that the evaluation of a policy is not only done in the final stage but it is also done through the whole process. In other words, the evaluation of a policy includes the stage in which the problems of the policy are formulated, the problems proposed to adjust the policy problems, its implementation, and the stage in which the impact can be identified.

According to Muhadjir (in Widodo, 2008: 112), the evaluation of a public policy is a process for evaluating how successful a public policy is by comparing the result already achieved and the target already determined. Evaluation is one of the stages in the public policy process; it is a way of evaluating whether a policy or program works or does not work. 
d) Job Performance in Public Services

Integrity, professionalism, neutrality, being free from any pressure and being not contaminated by Corruption, Collusion, and Nepotism are needed to have a high job performance in carrying out public services. Therefore, the implementation of the public services functions to unify the Pancasila and the 1945 Constitution-based nation. Performance refers to how well an employee can do his/her job, and this is usually used as the basis for assessing him/her and the organization for which he/she is employed. A good performance is one of the requirements needed to achieve the goal of the organization. Therefore, attempts should be made to improve the performance of employees.

It is not easy to improve performance as there are many factors which can cause someone's performance to be either high or low. The performance of human resources refers to the quality and quantity of the output they achieve during each period of their employment (Mangkunegara, 2006). The performance of an employee is one of the most important things needed by a company to achieve the goal already determined; therefore, attempts should be made to improve performance. Performance can be defined as what has been achieved in relation to the goal already planned. According to McDaniel (Uno \& Lamatenggo, 2012:62), performance refers to an interaction between the ability of someone and his/her motivation. Based on this view, it can be affirmed that performance refers to the combination of someone's ability and his/her motivation. According to Guritno \& Waridin (2005), performance refers to the comparison of the output achieved by an employee with the standard already determined. Many studies have been conducted to explore the public services provided by the government's apparatus. One of the studies was conducted by Ismayanti (2005) in Seragen regency. He found that the paradigm had changed from the paradigm of being served into the paradigm of serving sincerely. Actually, the bureaucratic performance of the government's apparatus can be viewed from different dimensions such as productivity, quality of services, responsiveness, responsibility, and accountability.

According to Dwiyanto (2002), the criteria of the public services are as follows: (a) efficiency, namely the profit successfully obtained by the public serving organization, the production factors and rationality should be taken into account, (b) effectiveness, namely how effective the public serving organization achieves its goal, (c) justness, namely how the public serving organization distributes and allocates services, (d) responsiveness, namely the ability to give response to what the community needs. Dwiyanto (2005) uses two approaches to measure the performance of public services; they are (a) the first approach which is used to measure the performance of the public services from the perspective of the service provider, and (b) the second approach which is used to measure the performance of the public services from the service user. These two approaches should be viewed from the interconnected and interdependent viewpoints. According to Dwiyanto et al., (2012), it is not enough to view the public services using the indicators attached to bureaucracy, namely efficiency and effectiveness but it should also be viewed from what has been done in Manado. It seems that the performance of the employees has not been as optimal as expected. The fact that the permit providing the function of the institution has not been optimal qualitatively and quantitatively indicates this. As stipulated in the Regulation of the Mayor of Manado City No. 40 of 2008 concerning the Detailed Basic Responsibility and Function of the Integrated Permit Issuing Unit, and the Regulation of the Mayor of Manado City No. 06 of 2009 concerning the Issuance of Permits by what is referred to as BP2T of Manado City that this Unit handles the issuance of 19 types of permits which are divided into four areas; they are 4 (four) types of permits issued for economic activities, 4 (four) types of permits issued for construction activities, 4 (four) types of permits issued for touristic activities, and 7 (seven) types of permits issued for industrial and trading activities. Based on the Report of the Accountability of the Government Institutions' Performance 'Laporan Akuntabilitas Kinerja Instansi Pemerintahan (LAKIP)', the performance achieved by the Integrated Permit Issuing Unit of Manado City has not been optimal yet. The fact shows that the quality of the serving procedure has not been good yet; the administrative fact and the serving technique, according to the user, are still complicated; permits are often issued not in time.

e) The Policy of Remuneration to Improve the Performance of the Police of the Republic of Indonesia

The policy of remuneration is one of the government's strategies to improve the welfare of the government civil servants in Indonesia. It is expected that this policy can lead to a breakthrough to the phenomenon showing the current bad image of the apparatus. The corrupting behavior of the apparatus in almost every institution of the central government and local government worsens the image.

Astina, I. K., Sukristyanto, A., \& Darmawan, A. (2018). Improving policy of the Republic of Indonesia performance in Bali regional police environment. International Journal of Social Sciences and Humanities, 2(3), $156-172$. https://doi.org/10.29332/ijssh.v2n3.226 
The policy of remuneration is regulated by issuing the Act of the Civil Servants No. 5 of 2014. In clause (1) article 80, it is stated that the Police apparatus also receive allowances and facilities apart from salaries. In clause (2), it is stated that allowances include the performance allowance and overpriced allowance. This stipulation also applies to all the members including those who are employed at the Operating Bureau of the Bali Regional Police. In Article 3 clause (2) of the Regulation of the Chief of the Police of the Republic of Indonesia, and Article 10 of the Presidential Regulation No. 89 of 2015 concerning Remuneration for the employees employed at the Police of the Republic of Indonesia, it is necessary to determine the way of giving the performance allowance to the employees employed in the environment of the Police of the Republic of Indonesia. As stated in clause (2) article 3, remuneration is given as an attempt to improve the welfare of the employees employed under the Operating Bureau of the Bali Regional Police based on the workload or the working condition or the scarcity of the profession and the achievement achieved. The principle which should be adhered to ascertain that remuneration is closely related to performance is that there is a clear and definite measure for it. In this case, what is important is making sure that the performance of every employee within the organization can be well measured.

\section{Materials and Methods}

Based on what was described in the background, the current study only explains the phenomena which were taking place in the field as they were when the study was being conducted. To this end, the current study was intended to evaluate the policy of the remuneration given to the employees employed in the environment of the Bali Regional Office. It was expected that the qualitative approach can describe the phenomena investigated comprehensively which finally can answer the problems formulated in the study, meaning that the study can achieve its objectives.

The study was conducted as carefully and comprehensively as possible so that the result can be in the form of a comprehensive description. However, the focus should be determined to enable the study to answer the problems investigated more sharply and to make the study focused on the problems of the study only. The focus of the study plays an important role, as it can be used to decide what data would be collected and what data would not be used. The scope of the current study is the policy of remuneration and the performance of preparing public services. The focus of the study is directed at evaluating to what extent the policy of remuneration has achieved the objectives and targets already determined. One of the objectives and targets of the policy is improving the performance of the Personnel of the Police when serving the public. To make the data valid, the data were collected through several steps including credibility. The researcher was patient, diligent and patient when the researcher collected the data at the location where the study was conducted, namely the Operating Bureau of the Bali Regional Police to make the data valid. The researcher also triangulated the data source, the method and theories used.

The data were processed using the model proposed by Miles \& Huberman (1994) with a consideration that this model is in accordance with the matters pertaining to the Evaluation of the Policy of Remuneration as an Attempt to Improve the Performance of the Public Services Provided by the Operating Bureau of the Bali Regional Police. The analysis can be described as follows. 


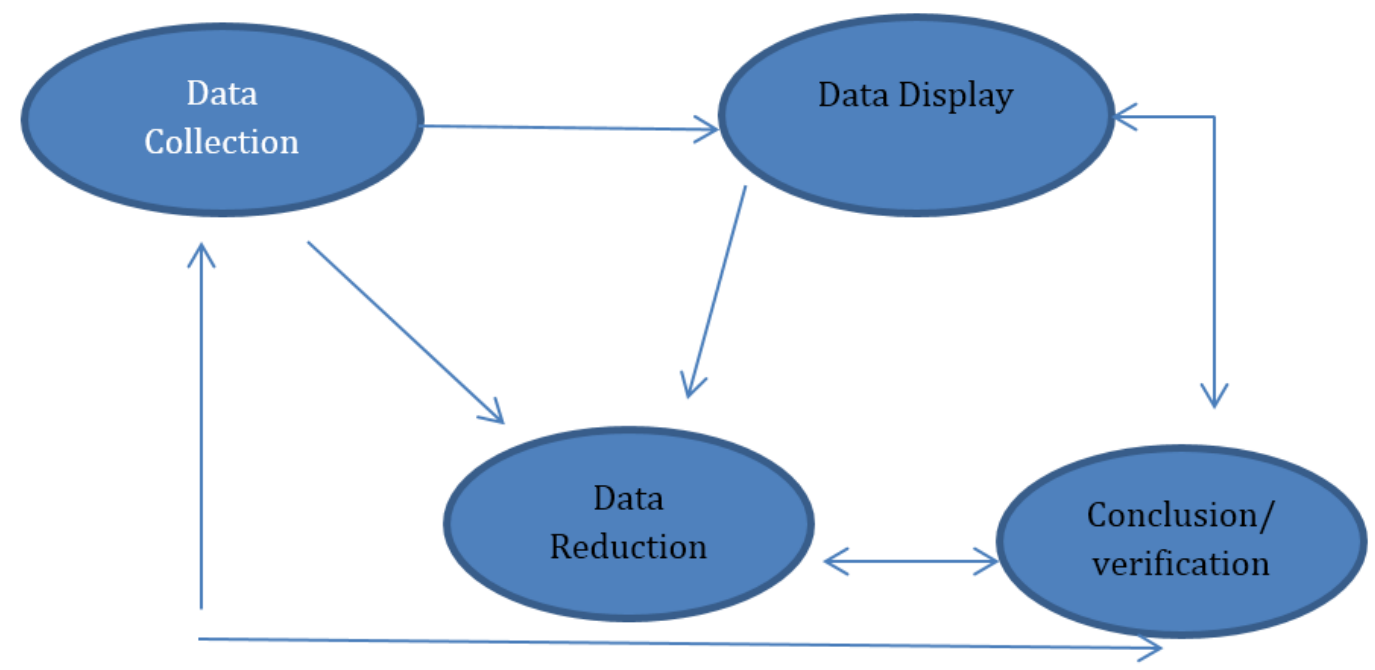

Figure 1. Data Analysis

Source: Miles \& Hubermen (1994)

\section{Results and Discussions}

\subsection{Result}

Effectiveness is one of the achievements intended to be achieved by an organization. The theory of effectiveness was adopted from the concepts used in the theory of management and the organizational theory, especially those related to the theory of effectiveness. Effectiveness cannot be made to be identical with efficiency. They have different meanings although the use of the word efficiency cannot be separated from the use of the word effectiveness. Efficiency is defined as the comparison between cost and output, and effectiveness is directly connected with the achievement of a goal. A policy is stated to be effective if the organization can achieve the target already expected completely. Effectiveness is generally considered the level in which the operative and operational goals are achieved. In short, basically, effectiveness refers to the level in which the determined goal or target of an organization is achieved as expected.

A public policy is considered the guidance chose by the decision maker to control particular aspects of a social problem. As guidance, a public policy directs the behavior in the future. At the same time, a public policy is a unified direction of a number of programs and projects which require small and big decisions. This direction is produced through the process of selecting a number of alternative policies; therefore, the resultant action is an intentional one. The choice made is not intended to solve all problems but it is a solution to a limited situation.

The Policy of Remuneration in the environment of the Bali Regional Office is regulated in the Regulation issued by the Chief of the Police of the Republic of Indonesia No. 13 of 213 dated 13 August 2015 concerning the Customs and Manners of Giving Remuneration to the employees employed at the environment of the Police of the Republic of Indonesia.

The policy of remuneration at the Bali Regional Office stipulates 2 (two) indicators. They are the indicator indicating the echelon-based value of remuneration and the indicator indicating the workload. Punishment includes a warning, supervision, mutation, and demotion. The reward and punishment approach is intended to motivate the Police of the Republic of Indonesia to work based on their responsibilities and functions so that the output achieved will improve. The improved performance of the Police of the Republic of Indonesia when serving the public will contribute to the improved performance of giving security services in the environment of the Bali Regional Police.

It is expected that the policy of remuneration for the employees employed in the environment of the Bali Regional Police can improve their welfare, which then causes them to improve their performance. The

Astina, I. K., Sukristyanto, A., \& Darmawan, A. (2018). Improving policy of the Republic of Indonesia performance in Bali regional police environment. International Journal of Social Sciences and Humanities, 2(3), 156-172. 
remuneration is monthly received by the Police members, causing them to be able to plan the needs of their lives. On the other hand, the remuneration is designed to direct the Police members, including those who are in the front line, to improve their discipline and performance so that the quality of the services provided is in accordance with the standard and procedure already determined.

Before the policy of remuneration was in effect in the environment of the Bali Regional Police, the implementer attempted to socialize it to all the Police members in the environment of the Bali Regional Police using the approach usually used in the morning and afternoon appeal. It was socialized through the meetings attended by the officials in the environment of the Bali Regional Police. After it was socialized to every division in the environment of the Bali Regional Police, it was then implemented by the Bali Regional Police.

Remuneration is an additional income given as an attempt to improve the welfare of the Police members based on the workload, the number of weekdays they are present at and return to work. For the interest in the calculation of the payment for the remuneration, the Police members are obliged to sign the attendance list of the morning and afternoon appeal. If the police members come later or leave the office earlier than they should, they will not be allowed to sign the attendance list.

The result of the study showed that, principally, the staff members of the Operating Bureau of the Bali Regional Police disagreed with how the value of the remuneration was calculated. They thought that how the value of the remuneration received by the Police members in the environment of the Bali Regional Police was calculated was not fair.

The amount of the remuneration received by one member was still different from that received by another. This reflects that the principle of "justness" or internal equity, which should have been used as the basis for calculating the amount of remuneration received by the Police members, was not referred to. Different types of allowances given by the Bali Regional Police were not based on the performance of the employees; in other words, a particular method which was regarded as being able to motivate the productivity the Police members had not been used as the basis yet. In addition, there was not any uniformity in terms of how the remuneration was budgeted and organized. Therefore, it is necessary for the Police to create a model policy referred to as TTP (Tunjangan Tambahan Penghasilan) "remuneration" which can contribute to the performance of the Police of the Republic of Indonesia.

In so far as the policy of remuneration which has been paid is concerned, it seems that there is no clear relationship between the remuneration which has already been paid with the indicators of performance; in addition, the political mechanism within bureaucracy still hampers the achievement of the goal of the policy. High commitment and hard work from all the elements, starting from the upper level of employees to the lower level of employees, are required to support the success of the policy of remuneration.

If the policy is accurately implemented, then the policy will be able to improve the performance of public services in the future. However, it is important to know that the remuneration which is currently replicated in many regions should be made to be really related to the indicator of the performance of the Police members where it is replicated. In this way, remuneration can improve the performance of the Police of the Republic of Indonesia as described in the following chart: 


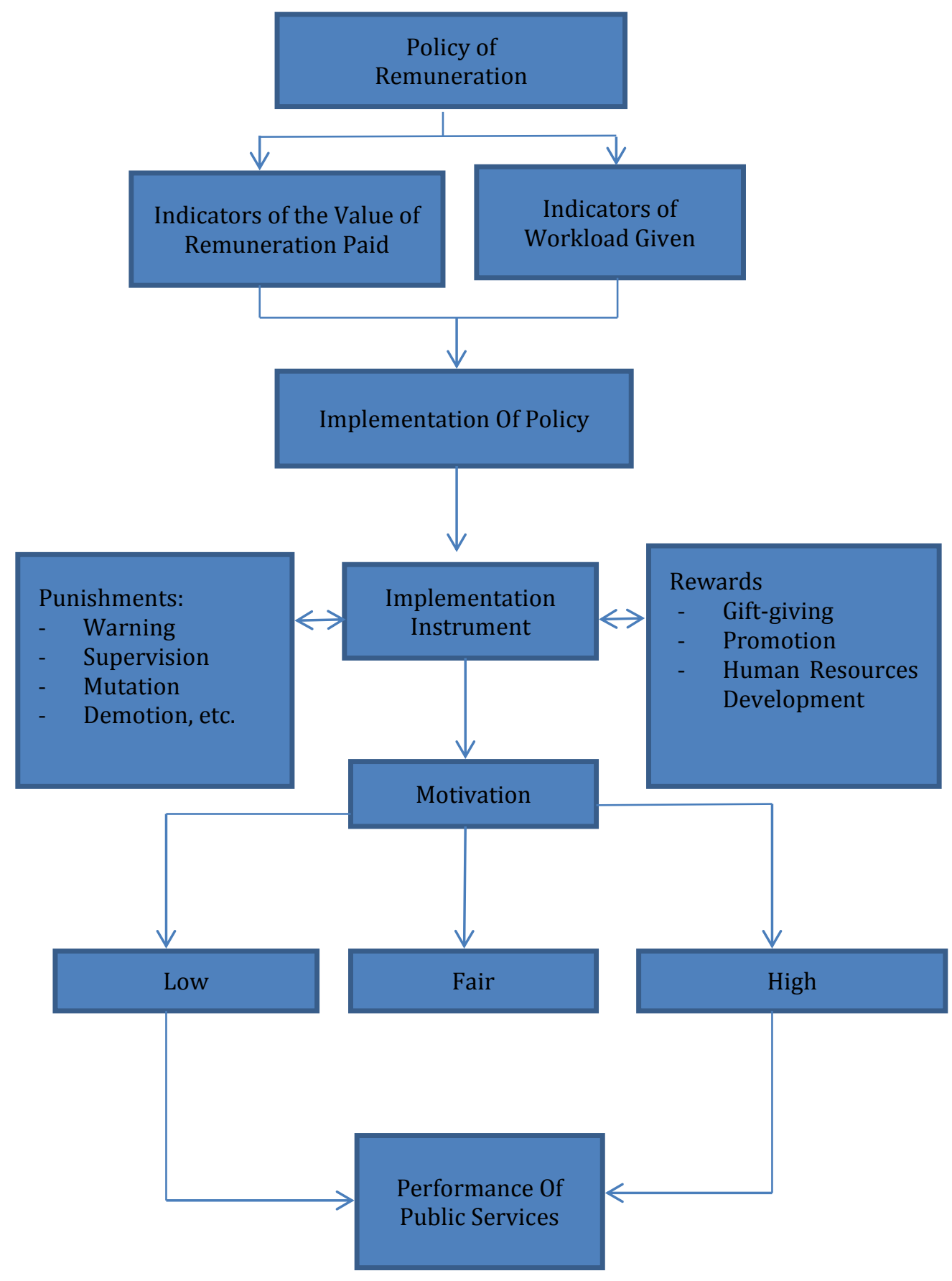

Figure 2. Policy of remuneration

Source: Processed from the result of the study

Astina, I. K., Sukristyanto, A., \& Darmawan, A. (2018). Improving policy of the Republic of Indonesia performance in Bali regional police environment. International Journal of Social Sciences and Humanities, 2(3), 156-172. https://doi.org/10.29332/ijssh.v2n3.226 


\subsection{Discussions}

The classification of the value of remuneration should be synchronized to the Rank, Echelon, Nivellering, Position, and Index of Remuneration. Based on the result of the study, as far as the remuneration paid to the employees in the Bali Regional Police is concerned, the theory proposed by House (Dunn, 2003) is required to solve the problems related to the policy of remuneration. He proposes several Models Evaluation of Public Policy; they are (1) The Adversan Model, in which the evaluators are grouped into two; they are those who are supposed to present the result of the evaluation of the positive program, the result of the effective and good policy, and those who are supposed to find out the result of the evaluation of the program which is negative, ineffective, fails and does not achieve the target.

The two groups are intended to guarantee the neutrality and objectivity of the evaluation process. Their findings are then assessed as the result of the evaluation. According to this model, there is no efficiency in terms of the collected data; (2) The Transaction Model; this model pays attention to the use of the method of the case study; it is naturalistic in nature and it can be grouped into two types; they are the responsive evaluation, namely the evaluation which is made through informal and repeated activities so that the program which has already been planned can be accurately pictured; and the illuminative evaluation, which is intended to analyze the innovative program in the framework of describing and interpreting the implementation of a policy program. In short, it can be stated that this model evaluation attempts to reveal the program which is planned, in which the researcher can independently make an evaluation and is in the position of being objective.

Therefore, accuracy is needed when evaluating the policy of remuneration. According to Dunn (2000), there are 6 (six) criteria which need to be fulfilled when evaluating a policy; they are:

a) Effectiveness, meaning that the target already determined is successfully achieved;

b) Efficiency, meaning that a number of attempts should be made to achieve a certain level of effectiveness;

c) Adequacy, meaning that the goal already achieved has already been felt to be adequate in different aspects;

d) Equality, meaning that the target of the public policy has been distributed and obtained equally;

e) Accuracy, which refers to the value or price of the goal of the program and how strong the assumption used as the basis for such a goal is;

f) Responsiveness, which can be defined as a response to an activity.

The evaluation of the performance of public services is closely related to the performance of employees. The performance of public services cannot be improved if the performance of employees is low. The higher the performance of employees the higher the performance of public services will be. According to Hasibuan (2005), the performance of an employee can be evaluated in several aspects. An employee is stated to be faithful if he/she does what he/she is supposed to do seriously and responsibly.

Moreover, according to Mathis and Jackson (2001), Performance (P) is the result of ability (A) which is multiplied by effort (E) and support (S), leading to the formula $\mathrm{P}=\mathrm{A} \times \mathrm{E} \times \mathrm{S}$. They further claim that performance will decrease if one of the factors is not available. Someone's ability refers to the natural ability involving the talent and interest which suit the job provided. Attempt refers to a practice required in an efficient and safe activity of an organization. The organizational support refers to the support received from the organization which can be in the forms of training, equipment, expectations and a productive work team. These show a high performance.

Based on the formula above, according to this theory, performance is the result of interaction among ability, attempt and support from the organization, meaning that if someone has high ability but the attempt he/she makes is low and the support given by the organization is low, then he/she will show low performance. Similarly, if someone has the low ability but the attempt he/she makes and the support given by the organization is high, then he/she will show low performance as well. An employee with high performance should have high ability and strong attempt and strong support from the organization.

According to Selim \& Woodward (Keban, 1995), performance can be viewed from economic consideration, efficiency, and effectiveness, and that adding/completing the facilities needed to support the fluency and the process of doing what is supposed to do based on what is required by the basic job and the organizational 
function is one of the ways of reducing the obstruction coming from the institution/organization. An employee is made to feel more satisfied by the fact that he/she has achieved the target than the reward he/she receives for the performance. This does not mean that he/she does not expect any reward but he/she prefers challenges. What an individual needs can be divided into three; they are the need for achievement (achievement motivation) which includes personal responsibility, the need for achievement, feedback and taking moderate risks. These needs are closely related to the job an individual does and direct behavior to the attempts which should be made in order to achieve a particular achievement;

Essentially, the abilities which someone has been composed of two sets of factors; they are the intellectual ability and the physical ability. The intellectual ability refers to the ability which is required to perform any mental activity, and the physical ability refers to the ability which is required to do a job which needs stamina, dexterity, strength, and skill.

The main objective of the policy of remuneration in the environment of the Bali Regional Police is to improve welfare which is then expected to improve the performance of the Police of the Republic of Indonesia when performing their job activities. This present study, as already stated above, is intended to evaluate the result and impact of the policy of remuneration implemented by the Bali Regional Police in general and the Operating Bureau of the Bali Regional Police in particular.

Based on the information obtained by deeply interviewing the informants in the environment of the Bali Regional Police, as far as the implementation of the policy of remuneration in the environment of the Bali Regional Police is concerned, it was revealed that the value of the remuneration had not been justly determined, and that the amount of the remuneration received by one member was different from that received by another member, meaning that the principle of justness or internal equity, which should have been used as the guidance, had not been implemented. A model policy of remuneration, that is, the incremental model proposed by Lindblom (quoted in Wibawa, 1994) is needed to solve the problem mentioned above. Basically, the Incremental Model criticizes the rational model. The criticism was firstly posted by Charles Lindblom.

Basically, the incremental model is pragmatic or practical in nature. The reason is that it considers the public policy the continuation of the activities done by the government in the past which have been modified as needed. This model is relevantly used to revise the policy of remuneration implemented by the Bali Regional Police. The reason is that it can revise the policy which is partially revised.

There are several reasons why the incremental approach is used; they are:

a) The policymakers do not have sufficient time, adequate intellectuality and enough funds for investigating the social values used as the basis for formulating the objective of the policy;

b) They are afraid that the unexpected impact will possibly appear resulting from the policy which has never been made before;

c) There is an interest that the results of the policy earlier made should be maintained;

d) There is an intention to avoid any conflict resulting from having to be involved in in the tiring process through which a new policy is made.

What tends to appear is the repetition of the earlier made programs with some slight modifications. The reason which is easily given by the administrators is that a new policy is always marginalized as the decision makers still hesitate the significance and effectiveness of the newly created program. The programs which have been implemented for years are easily approved.

As the remuneration which has already been paid by the Police of the Republic of Indonesia is not the only thing which can improve the performance of the Police members, and, based on the information obtained through the in-depth interview, it can be concluded that many members of the Police were not satisfied with how the remuneration paid to the employees employed at the Bali Regional Office was calculated. It is necessary for the Bali Regional Police to take steps which can lead to the solution to the problem. A model policy of remuneration which is fair and can improve the performance of the Police of the Republic of Indonesia should be created. According to the researcher, the Bali Regional Police needs to evaluate the way of determining the value of remuneration through the meetings involving the leaders of the police in the regency or city level 'Polres/ta' under the Bali Regional Police. Then the results of the meetings need to be socialized to the members in the regency/city levels under the Bali Regional Police. After that, the result of the socialization is used as a reference for revising the way of determining the value of remuneration. It is expected that the

Astina, I. K., Sukristyanto, A., \& Darmawan, A. (2018). Improving policy of the Republic of Indonesia performance in Bali regional police environment. International Journal of Social Sciences and Humanities, 2(3), 156-172. https://doi.org/10.29332/ijssh.v2n3.226 
new model policy of remuneration can justly calculate the value of the remuneration and include the principle of reward and punishment.

The reward is made to appear to motivate the employees to work hard when doing what they are supposed to do as they assume that the reward is given for the output they have produced. In this way, the Police members will work optimally. Punishment is made to appear for those who have made mistakes and violations. In this way, they will never behave wrongly anymore and will direct their behavior positively.

Based on what was stated above, it can be concluded that reward and punishment are used to motivate the Members of the Operating Bureau of the Bali Regional Police to perform optimally. Therefore, it is expected that those who are in the upper level can manage the system of reward and punishment well.

The result of the study described above is supported by the result of the study conducted by Koencoro et al., (2012) in which it was stated that the variables of reward and punishment collectively contribute to the variable of the employee's performance, meaning that reward and punishment can be achieved as the basis for predicting the performance of employees.

According to Nawawi (2005: 319), the reward is an attempt to cause a feeling of being accepted in the work environment to rise. This touches the aspect of compensation and the aspect of the relationship between one employee to another. The organization's leader evaluates the result of the performance of every individual formally and informally. According to Matteson in Koencoro (2013:2), the reward can be divided into two; they are an intrinsic reward and extrinsic reward. The extrinsic reward is made up of financial appreciation such as salary, allowance, bonus/incentive, and the intrinsic reward is a type of self-managed appreciation, starting from the solution, achievement, and autonomy.

The policy of remuneration provided by the Bali Regional Police will lead to working motivation. Motivation refers to a process within one's self-causing one to move in such a way that one will achieve one's goal or causing one to keep away from an unpleasant situation. Motivation is a potential strength within one's self which can be developed by one's self or which can be developed by a number of external strengths, which, basically, ranges from the financial reward and non-financial reward, which can either positively or negatively affects the output produced by a member of the Police, depending on the situation and condition he or she faces. Motivation results from the processes which are either internal or external to one individual, causing him/her to be enthusiastic and persistent in following the direction of certain actions.

\section{Conclusion}

The finding of the current study which explored the policy of remuneration paid to the members of the Police of the Republic of Indonesia employed in the environment of the Bali Regional Police shows that the policy of remuneration has not been effective; as a consequence, it has not been able to improve the performance of public services provided at the Operating Bureau of the Bali Regional Police optimally; therefore, the performance needs to be improved. The reasons are that: (1) the members of the Police of the Republic of Indonesia perceive that the payment for the remuneration by the Bali Regional Police is only intended to improve the members' welfare and to improve their discipline to sign the attendance list when they are present at and return to work. (2) The members of the Police of the Republic of Indonesia also perceive that the remuneration is intended to increase their income as the prices of their daily needs are going up, meaning that the remuneration they receive is intended to adjust their purchasing ability to the increase in the prices of the primary needs. This indicates that some members of the Police of the Republic of Indonesia consider that the payment for the remuneration is only for self-interest even though the payment for the remuneration is intended to improve the members' welfare (for the interest of the Police of the Republic of Indonesia) and to improve performance (for the interest of the institution). The perception of the Bureaucratic apparatus at the Bali Regional Police has caused the performance of the policy of remuneration not to achieve the goal and target desired by the Bali Regional Police optimally yet. Furthermore, when the policy of remuneration was realized many members disagreed with the Bali Regional Police Chief and stated that the remuneration provided to the members or the bureaucratic apparatus did not have anything to do with the performance of the Police of the Republic of Indonesia and that it only had something to do with the presence at and return to work. 
Acknowledgments

The authors would like to thank the reviewer for their consideration the further step process. Thank the editor of the journal for their support, valuable time and advice.

Astina, I. K., Sukristyanto, A., \& Darmawan, A. (2018). Improving policy of the Republic of Indonesia performance in Bali regional police environment. International Journal of Social Sciences and Humanities, 2(3), 156-172. https://doi.org/10.29332/ijssh.v2n3.226 


\section{References}

Bridgman, P., \& Davis, G. (2004). The Australian policy handbook. Allen \& Unwin.

Bromley, D. W. (1989). Economic interests and institutions: the conceptual foundations of public policy. Daniel W. Bromley. New York and Oxford: Basil Blackwell.

Dwiyanto, A. (1995). Penilaian Kinerja Organisasi Pelayanan Publik. In Makalah Seminar Kinerja Organisasi Pelayanan Publik tanggal (Vol. 20).

Dwiyanto, A. (2000). Membangun Sistem Pelayanan Publik Yang Memihak Pada Rakyat. Populasi, 13(1).

Dwiyanto, A. (2006). Reformasi birokrasi publik di Indonesia. Gadjah Mada University Press.

Dwiyanto, A. (2012). Mewujudkan Good Governance melalui Website: http://www. ejournal-s1. undip. ac. id/index. php/dlr. Pelayanan Publik Yogyakarta: UGM.

Dwiyanto, A. (Ed.). (2005). Mewujudkan good governance melalui pelayanan publik. Gadjah Mada University Press.

Gibson, D. G., Glass, J. I., Lartigue, C., Noskov, V. N., Chuang, R. Y., Algire, M. A., ... \& Merryman, C. (2010). Creation of a bacterial cell controlled by a chemically synthesized genome. science, 1190719.

Guritno, B. (2005). Waridin. 2005. Pengaruh Persepsi Karyawan Mengenai Perilaku Kepemimpinan, Kepuasan Kerja Dan Motivasi Terhadap Kinerja. JRBI, 1(1), 63-74.

Hasibuan, H. (2005). Malayu SP 2005. Manajemen Sumber Daya Manusia, 42-50.

Ismayanti, Y. (2005). Studi Perilaku Konsumen Pengguna Kartu GSM dan Kartu CDMA di Surabaya.

Keban, Y. T. (1995). Indikator Kinerja Pemda: Pendekatan Manajemen dan Kebijakan. Yogyakarta: Fakultas Ilmu Sosial dan Politik UGM.

Kuncoro, M. (2012). Perencanaan daerah: bagaimana membangun ekonomi lokal, kota, dan kawasan?. Salemba Empat.

Kuncoro, M. (2013). Economic geography of Indonesia: can MP3EI reduce inter-regional inequality. South East Asian Journal of Contemporary Business, Economics, and Law, 2(2), 17-33.

Lindblom, C. E. (1983). Politics and Markets: The World'S Political-Economics Systems.

Mangkunegara, A. P., \& Prabu, A. (2005). Evaluasi kinerja sumber daya manusia. Bandung: Refika Aditama.

Matteson, M. T., \& Ivancevich, J. M. (1987). Controlling work stress: Effective human resource and management strategies. Jossey-Bass.

McDaniel, C., \& Gates, R. (2013). Marketing research. Singapore.

Miles, M. B., \& Huberman, A. M. (1992). Analisis data kualitatif.

Miles, M., \& Huberman, M. (1984). Qualitative data analysis: a sourcebook of new methods (Beverly Hills, CA, Sage Publications).

Muhadjir, N. (2000). Metodologi penelitian kualitatif. Yogyakarta: Rake Sarasin.

Nahak, S. (2017). Criminal law policy on land functions impacting climate change in Indonesian national law perspective. International Journal of Social Sciences and Humanities, 1(3), 28-39.

Nawawi, H. (2005). Manajemen Strategik. Yogyakarta: Gadjah Mada Pers.

Parsons, S. L., Watson, S. A., Brown, P. D., Collins, H. M., \& Steele, R. J. C. (1997). Matrix metalloproteinases. British Journal of Surgery, 84(2), 160-166.

Sedarmayanti, M. P., \& Pd, M. Apu, 2009. Sumber Daya Manusia dan Produktivitas Kerja, Bandung.

Selim, G., \& Woodward, S. (1992). The manager monitored. Rediscovering Public Services Management, London: Mc-Graw Hill Book Company, 141-169.

Suharto, E. (2008, February). Corporate Social Responsibility: What is and Benefit for Corporate. In Makalah Seminar, Februari.

Sumitro, S., Kurokawa, S., Shimano, K., \& Wang, M. L. (2005). Monitoring based maintenance utilizing actual stress sensory technology. Smart materials and structures, 14(3), S68.

Suyata, S., Bustami, E., Bardiman, S., \& Bakry, F. (2004). A comparison of efficacy between rebamipide and omeprazole in the treatment of nsaids gastropathy. Indonesian Journal of Gastroenterology, Hepatology, and Digestive Endoscopy, 5, 89-94.

Tachjan, H. (2006). Implementasi kebijakan publik. Abstrak.

Uno, H. B., \& Lamatenggo, N. (2012). Teori kinerja dan pengukurannya. Jakarta: Bumi Aksara.

Wibawa, S., Purbokusumo, Y., \& Pramusinto, A. (1994). Evaluasi kebijakan publik. PT Raja Grafindo Persada.

Widodo, T. (2008). The Method of Constant Market Shares (CMS)-competitiveness effect reconsidered: Case studies of ASEAN countries. Journal of Indonesian Economy and Business, 23(3), 223-242. 
William, N. D. (2003). Pengantar Analisis Kebijakan Publik. Gadjah Mada University Press, Yogyakarta.

Astina, I. K., Sukristyanto, A., \& Darmawan, A. (2018). Improving policy of the Republic of Indonesia performance in Bali regional police environment. International Journal of Social Sciences and Humanities, 2(3), 156-172.

https://doi.org/10.29332/ijssh.v2n3.226 


\section{Biography of Authors}

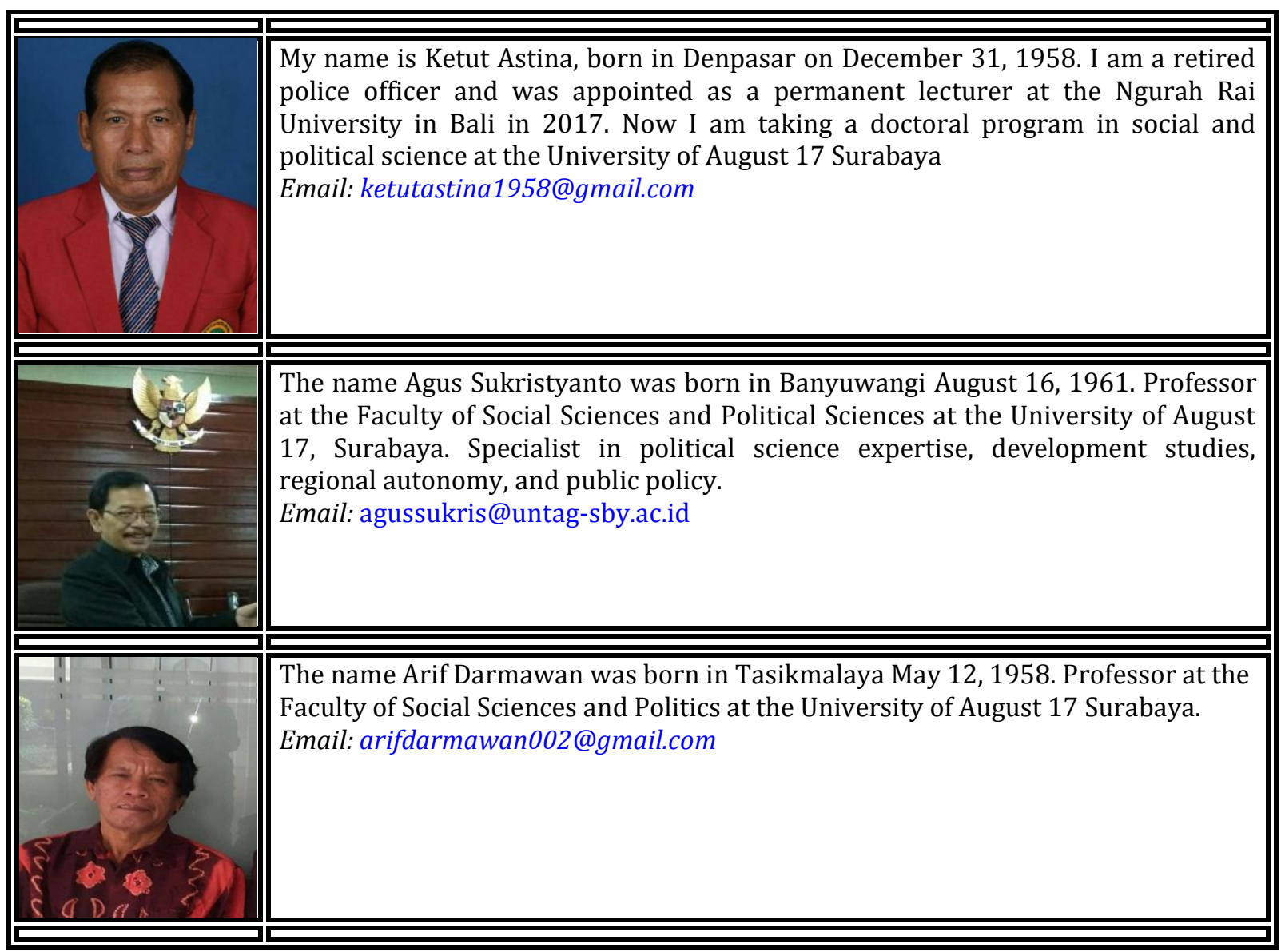

